\title{
Description of Ancylobacter oerskovii sp. nov. and two additional strains of Ancylobacter polymorphus
}

Correspondence

Elke Lang

ela@dsmz.de
Several strains of aerobic bacteria have been reported to be able to utilize oxalate as a sole carbon and energy source. Most of them are facultative methylotrophs and/or facultative hydrogen-oxidizing chemolithoautotrophs; some belong to the genera Methylobacterium, Hyphomicrobium, Cupriavidus, Xanthobacter and Ancylobacter (Sahin, 2003), but the exact taxonomic positions of many strains are unclear. In this study, we investigated the physiological, genetic and phylogenetic characteristics of three Ancylobacter strains, which were isolated by enrichment in mineral medium with potassium oxalate as described by Sahin et al. (2002). Members of the genus Ancylobacter play an important ecological role in oligotrophic methylotrophy and $\mathrm{H}_{2}$-lithotrophy (Raj, 1989; Aragno \& Schlegel, 1992). The genus Ancylobacter is assigned to the family Hyphomicrobiaceae according to the chapter by Garrity et al. (2005) in Bergey's Manual; however, Lee et al. (2005) found that the genera included in the Hyphomicrobiaceae in Bergey's Manual form two independent branches and thus established the families

The GenBank/EMBL/DDBJ accession number for the 16S rRNA gene sequence of strain $\mathrm{NSO5}^{\top}$ (=DSM $18746^{\top}$ ) is AM778407.
Xanthobacteraceae and Hyphomicrobiaceae, with Ancylobacter falling within the Xanthobacteraceae. The genus presently comprises four species with validly published names: Ancylobacter aquaticus (Ørskov, 1928; Raj, 1983), Ancylobacter rudongensis (Xin et al., 2004), Ancylobacter polymorphus and Ancylobacter vacuolatus (Xin et al., 2006). The present article deals with the taxonomic description of a novel species to accommodate soil isolate $\mathrm{NS}^{2} 5^{\mathrm{T}}$ and the description of two paper-mill isolates, NS03 and NS04, as additional strains of Ancylobacter polymorphus.

Among others, three strains of Gram-negative, non-motile, non-sporulating, strictly aerobic bacteria, designated NS03, NS04 and $\mathrm{NS}_{0} 5^{\mathrm{T}}$, were isolated from enrichment cultures containing potassium oxalate $\left(4 \mathrm{~g} \mathrm{l}^{-1}\right)$ as the sole source of carbon and energy (Sahin et al., 2002). The strains consisted of curved rods (NS03 and NS04) or pleomorphic rods $\left(\mathrm{NS}^{\mathrm{T}}{ }^{\mathrm{T}}\right.$; Fig. 1). Colonies of the strains were opaque, cream-coloured and convex.

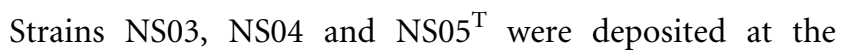
DSMZ with the accession numbers DSM 18745, DSM 19551 and DSM $18746^{\mathrm{T}}$, respectively. The following strains were used as references: Ancylobacter rudongensis DSM 


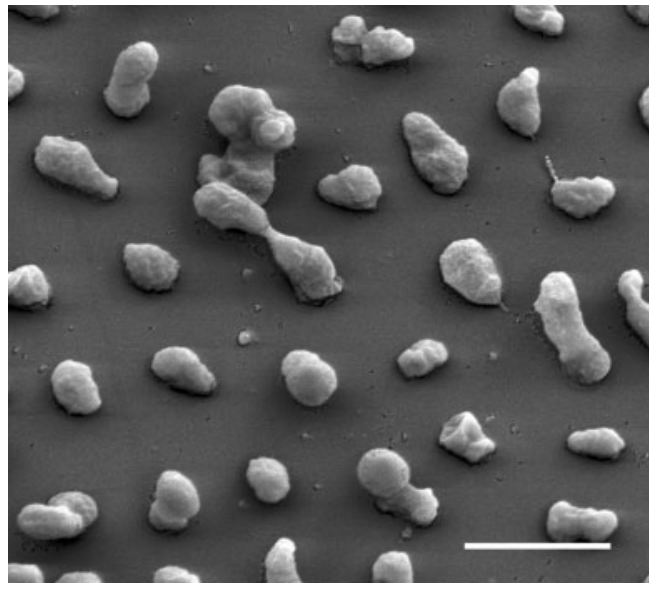

Fig. 1. Field-emission scanning electron micrograph of cells of strain $\mathrm{NS}^{\top}{ }^{\top}$, grown on an R2A agar plate, showing the variable cellular morphology. Bacteria were fixed with $2 \%$ glutaraldehyde and $5 \%$ formaldehyde in the culture medium for $1 \mathrm{~h}$ on ice. This was followed by washing with TE buffer (20 mM Tris, $1 \mathrm{mM}$ EDTA; $\mathrm{pH} 6.9)$ and dehydration in a graded acetone series (10, 30, 50, $70,90,100 \%)$ on ice (15 min for each step), critical-point drying with liquid $\mathrm{CO}_{2}$ (CPD 30 ; Balzers) and sputter-coating with a gold film (SCD 40; Balzers). The Zeiss microscope (DSM 982 Gemini) was used with an Everhart-Thornley secondary electron detector and the in-lens detector in a 50:50 ratio at an acceleration voltage of $5 \mathrm{kV}$. Bar, $2 \mu \mathrm{m}$.

$17131^{\mathrm{T}}, \quad$ Ancylobacter polymorphus DSM $2457^{\mathrm{T}}$, Ancylobacter vacuolatus DSM $1277^{\mathrm{T}}$ and Ancylobacter aquaticus DSM $101^{\mathrm{T}}$. The strains were grown routinely on nutrient agar (Difco) (containing $5 \mathrm{~g}$ peptone, $3 \mathrm{~g}$ beef extract and $15 \mathrm{~g}$ agar agar $\left.1^{-1}\right)$ at $28{ }^{\circ} \mathrm{C}$.

$16 \mathrm{~S}$ rRNA gene sequences were generated and aligned as described by Somvanshi et al. (2006). Phylogenetic dendrograms were constructed using the algorithms of De Soete (1983) and Saitou \& Nei (1987). Analysis of the $16 \mathrm{~S}$ rRNA gene sequences resulted in the grouping of all three isolates within the family Xanthobacteraceae. The sequences of the $540 \mathrm{bp} \mathrm{5'}$ termini of the sequences of strains NS03 and NS04 were identical and the almostcomplete sequence of strain NS04 was identical to the sequence of the type strain of Ancylobacter polymorphus, DSM $2457^{\mathrm{T}}$. This is in accord with the morphological appearance (curved rods) and the classification of these strains in the genus Ancylobacter on the basis of the physiological features determined in a previous study (Sahin et al., 2002).

Strain $\mathrm{NS} 5^{\mathrm{T}}$ shared the highest $16 \mathrm{~S}$ rRNA gene sequence similarity with Ancylobacter rudongensis AS $1.1761^{\mathrm{T}}$ (98.1\%). Phylogenetic analysis using different distancematrix algorithms consistently showed these two strains to be neighbours, while the positions of members of the genera Ancylobacter, Starkeya and Angulomicrobium depended somewhat on the selection of reference sequences included in the analysis. In several cases, the genus Ancylobacter did not emerge as a coherent genus, but members of the genera Angulomicrobium and Starkeya together with Ancylobacter rudongensis and strain $\mathrm{NS}^{\mathrm{T}} 5^{\mathrm{T}}$ formed a separate clade. Although the relationships between the three genera have not been fully explored, the overall chemotaxonomic similarity of Ancylobacter strains supports the observation that the genus is phylogenetically coherent (Fig. 2; based on the algorithm of De Soete, 1983). This interpretation corresponds with the results of a 16S rRNA gene sequence analysis by Fritz et al. (2004), which confirmed the genus status of Angulomicrobium, clustering separately from Ancylobacter aquaticus. No 16S rRNA gene sequence is available for a strain of the species 'Ancylobacter natronum' (Doronina et al., 2001), and the name of this species has not yet been validly published.

For DNA-DNA hybridization, DNA was isolated using a French pressure cell (Thermo Spectronic) and was purified by chromatography on hydroxyapatite as described by Cashion et al. (1977). Hybridization was carried out in SSC buffer at $68{ }^{\circ} \mathrm{C}$ as described by De Ley et al. (1970), with the modifications described by Huß et al. (1983), using a Cary $100 \mathrm{Bio}$ UV/Vis spectrophotometer equipped with a Peltier-thermostatted $6 \times 6$ multicell changer and a temperature controller with an in situ temperature probe (Varian). For determination of the $\mathrm{G}+\mathrm{C}$ content, DNA was degraded to nucleosides by using P1 nuclease and bovine intestinal mucosa alkaline phosphatase, as described by Mesbah et al. (1989). The nucleosides were separated by reversed-phase HPLC (Shimadzu apparatus) according to the method described by Tamaoka \& Komagata (1984), and the $\mathrm{G}+\mathrm{C}$ content was calculated from the ratio of deoxyguanosine to thymidine.

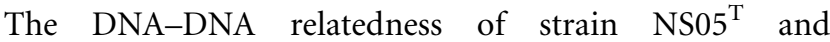
Ancylobacter rudongensis DSM $17131^{\mathrm{T}}$, sharing a $16 \mathrm{~S}$ rRNA gene sequence similarity of $98.1 \%$, was $17 \%$, which

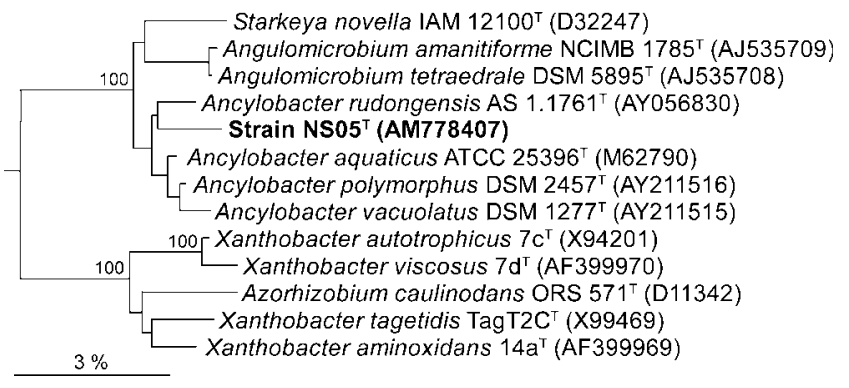

Fig. 2. Additive phylogenetic tree (De Soete, 1983), based on 16S rRNA gene sequences, showing the closest neighbours of strain $\mathrm{NSO}^{\top}$ within the genus Ancylobacter and phylogenetically related genera. Bootstrap percentages (based on 500 datasets) are shown at branch points (if greater than 60\%). Bar, 3\% difference in nucleotide sequences, as determined by measuring the lengths of the horizontal lines connecting any two organisms. 
confirms that strain $\mathrm{NS}^{2} 5^{\mathrm{T}}$ does not belong to the genospecies Ancylobacter rudongensis. The DNA G+C content of strain $\mathrm{NS} 5^{\mathrm{T}}$ was $68.0 \mathrm{~mol} \%$, which is within the range (65.5-68.2 mol\%) previously obtained for Ancylobacter species (Urakami \& Komagata, 1986; Xin et al., 2004, 2006).

For the analysis of fatty acids, cells were grown on R2A agar (DSMZ medium 830; http://www.dsmz.de) for $48 \mathrm{~h}$ at $28{ }^{\circ} \mathrm{C}$. This growth medium was used instead of the tryptic soy broth agar recommended for use with the MIDI system. The Ancylobacter reference strains did not grow well on the latter medium, and the composition of R2A agar is similar to the composition of the MicrocyclusSpirosoma agar used by Urakami \& Komagata (1986) for fatty acid analysis. Whole-cell fatty acid methyl esters were obtained using methods described previously (Kämpfer \& Kroppenstedt, 1996) and were separated using a gas chromatograph (model 5898A; Hewlett Packard). Peaks were automatically integrated and fatty acid names and percentages were determined using the Microbial Identification standard software package (MIDI) (Sasser, 1990). The fatty acid profile of strain $\mathrm{NS}^{2} 5^{\mathrm{T}}$ was dominated by $\mathrm{C}_{18: 1} \omega 7 c \quad(60.4 \%), \mathrm{C}_{19: 0} \omega 8 c$ cyclo $(28.3 \%)$ and $\mathrm{C}_{16: 0}(7.4 \%)$ (Table 1$)$. The fatty acid compositions of members of the genus Ancylobacter were not included in earlier species descriptions. However, Urakami \& Komagata (1986) included several strains of Ancylobacter aquaticus (analysed as Microcyclus aquaticus; the bacterial genus name Microcyclus is illegitimate), including ATCC $25396^{\mathrm{T}}$, and Ancylobacter polymorphus (analysed as 'Microcyclus polymorphum') NCIB $10516^{\mathrm{T}}$ in their studies. The patterns generated in the present study

Table 1. Whole-cell fatty acid composition of strain $\mathrm{NSO5}^{\top}$ and Ancylobacter type strains

Strains: 1, strain $\mathrm{NS}_{0} 5^{\mathrm{T}} ; 2$, Ancylobacter rudongensis DSM $17131^{\mathrm{T}} ; 3$, Ancylobacter aquaticus DSM $101^{\mathrm{T}}$; 4, Ancylobacter vacuolatus DSM $1277^{\mathrm{T}}$; 5, Ancylobacter polymorphus DSM $2457^{\mathrm{T}}$. Cells were grown on R2A agar at $28{ }^{\circ} \mathrm{C}$ for 2 days. Data shown are percentages of total fatty acids. -, Not detected; ECL, equivalent chain length.

\begin{tabular}{|lccccc|}
\hline Fatty acid & $\mathbf{1}$ & $\mathbf{2}$ & $\mathbf{3}$ & $\mathbf{4}$ & $\mathbf{5}$ \\
\hline Unknown ECL 13.957 & 0.2 & 0.2 & 0.3 & - & 0.3 \\
Summed feature $3^{*}$ & $0-0.5$ & 1.3 & 1.4 & 0.7 & 0.4 \\
$\mathrm{C}_{16: 0}$ & 7.4 & 4.8 & 6.4 & 4.9 & 6.8 \\
$\mathrm{C}_{17: 0}$ & 0.4 & 0.5 & 1.0 & 1.1 & 0.9 \\
$\mathrm{C}_{18: 1} \omega 7 c$ & 60.4 & 60.9 & 71.7 & 76.1 & 71.5 \\
$\mathrm{C}_{18: 0}$ & 2.4 & 1.5 & 1.5 & 1.2 & 2.0 \\
$11-$ Methyl C $18: 1 \omega 7 c$ & - & 2.2 & - & 1.0 & 0.4 \\
Summed feature $7^{\star}$ & - & - & - & - & 0.8 \\
$\mathrm{C}_{19: 0} \omega 8 c$ cyclo & 28.3 & 27.9 & 17.4 & 14.7 & 16.3 \\
$\mathrm{C}_{20: 2} \omega 6,9 c$ & - & 0.35 & - & - & 0.2 \\
\end{tabular}

${ }^{*}$ Summed feature 3 contains $\mathrm{C}_{16: 1} \omega 7 c$ and/or iso- $\mathrm{C}_{15: 0} 2-\mathrm{OH}$; summed feature 7 contains one or more of $\mathrm{C}_{19: 0} \omega 10 c$ cyclo, $\mathrm{C}_{19: 1} \omega 6 c$ and unknown ECL 18.846 . generally agree with those published by Urakami \& Komagata (1986): while the major components are the same in both studies, they may differ in quantity. A major significant deviation is the absence of $\mathrm{C}_{14: 0} 3-\mathrm{OH}$ in the present study (Table 1). This acid was described as being present in all 'Microcyclus' strains (in amounts ranging from 1.5 to $2.8 \%$ ) by Urakami \& Komagata (1986). It is possible that the growth medium selected and the age of the cells used could have influenced the fatty acid composition, as shown by Urakami \& Komagata (1973). This suggestion is corroborated by the detection of minor amounts $(0.2 \%)$ of $\mathrm{C}_{14: 0} 3-\mathrm{OH}$ in cells of $\mathrm{NS}^{2} 5^{\mathrm{T}}$ cultivated on tryptic soy broth agar (data not shown).

Isoprenoid quinones were extracted from lyophilized cells according to the method of Collins et al. (1977) and the profile was analysed by reversed-phase HPLC (using the Shimadzu system based on solvent-delivery module LC20AD) (Groth et al., 1997). The main component was Q-10 and minor amounts of Q-9 were also present, the Q-10/Q-9 ratio being $9: 1$. This result was in accord with the grouping of strain $\mathrm{NS}^{2} 5^{\mathrm{T}}$ within the genus Ancylobacter, since Microcyclus aquaticus and 'Microcyclus polymorphus' also contained Q-10 as the major component (Urakami \& Komagata, 1986). However, these authors detected Q-11, in addition to Q-9, as a minor component.

Conventional biochemical tests were performed, according to standard methods (Smibert \& Krieg, 1994), after incubation at $28{ }^{\circ} \mathrm{C}$ for up to 10 days. Chemolithoautotrophy with $\mathrm{H}_{2}$ was tested in mineral medium under a microaerobic atmosphere containing $60 \% \mathrm{H}_{2}$ (Malik, 1988). API 20NE and API $50 \mathrm{CH}$ strips (bioMérieux) were used according to the manufacturer's instructions. Utilization of carbohydrates (API $50 \mathrm{CH}$ strips) was determined with modified AUX medium in which growth factors and amino acids had been replaced with yeast extract $\left(0.1 \mathrm{~g} \mathrm{l}^{-1}\right)$; results were read after 2 days.

All Ancylobacter strains tested were able to grow with oxalate as the sole source of carbon. Thus this capacity seems to be a common trait of the genus Ancylobacter rather than a unique feature of the strains isolated here using oxalate as the sole source of carbon. For $\mathrm{NS} 05^{\mathrm{T}}$, clumpy growth was observed in liquid batch cultures with oxalate. Optimal growth occurred at $\mathrm{pH} 7$ and $30{ }^{\circ} \mathrm{C}$ with potassium oxalate at $8 \mathrm{~g} \mathrm{l}^{-1}$; the maximum potassium oxalate concentration tolerated was $25 \mathrm{~g} \mathrm{l}^{-1}$ if the $\mathrm{pH}$ was not corrected during growth. This limit was probably due to the $\mathrm{pH}$ increase in the medium that occurred during metabolism of the oxalic acid.

Physiologically, strains NS03 and NS04 showed the same properties as the type strain of Ancylobacter polymorphus (DSM $2457^{\mathrm{T}}$ ) except that they cleaved urea when incubated for 6 days and NS04 utilized glycerol (Table 2). This supports the view that strains NS03 and NS04 should be regarded as members of the species Ancylobacter polymorphus. The study of their physiological properties 
Table 2. Morphological and physiological characteristics of strains NS03, NS04 and $\mathrm{NS}^{\top}{ }^{\top}$ and the type strains of the genus Ancylobacter

Strains: 1, NS05 ${ }^{\mathrm{T}}$; 2, Ancylobacter rudongensis DSM 17131 ${ }^{\mathrm{T}}$; 3 , Ancylobacter aquaticus DSM 101 ${ }^{\mathrm{T}} ; 4$, Ancylobacter vacuolatus DSM $1277^{\mathrm{T}}$; 5, Ancylobacter polymorphus DSM $2457^{\mathrm{T}} ; 6$, NS03; 7, NS04. All strains were positive for growth in the presence of $4 \% \mathrm{NaCl}$ and for utilization of oxalate, D-xylose and formate. In API 20NE strips, all strains were positive after 2 days for assimilation of glucose (except NS03) and mannitol and oxidase activity and all strains were negative for indole production, glucose acidification, arginine dihydrolase, gelatin hydrolysis and assimilation of mannose, $\mathrm{N}$-acetylglucosamine, maltose, caprate, adipate, citrate and phenyl acetate. In API $50 \mathrm{CH}$ strips, all strains were positive after 2 days for utilization of galactose, glucose, mannitol, xylitol, adonitol and D- and L-arabitol; all strains were negative for utilization of the other substrates included in the panel. ND, Not determined; w, weak reaction.

\begin{tabular}{|c|c|c|c|c|c|c|c|}
\hline Characteristic & 1 & 2 & 3 & 4 & 5 & 6 & 7 \\
\hline Rod morphology & Pleomorphic & Curved & Curved & Curved & Curved & Strongly curved & Strongly curved \\
\hline Autotrophic growth with $\mathrm{H}_{2}$ & - & - & + & + & + & ND & ND \\
\hline Maximum growth temperature $\left({ }^{\circ} \mathrm{C}\right)$ on slant & 40 & 40 & 34 & 37 & 42 & 40 & 40 \\
\hline Nitrate reduction & - & - & + & + & - & - & - \\
\hline Urease & + & + & + & + & - & + & + \\
\hline \multicolumn{8}{|l|}{ Utilization of (conventional tests): } \\
\hline L-Fucose & + & - & - & + & - & - & - \\
\hline D-Arabinose & + & + & - & + & - & - & - \\
\hline D-Mannose & + & - & - & - & - & - & $\mathrm{W}$ \\
\hline L-Rhamnose & + & - & - & - & - & - & - \\
\hline D-Malate & + & $\mathrm{W}$ & + & - & + & + & + \\
\hline Malonate & + & + & + & + & - & - & - \\
\hline Gluconate & + & - & + & + & - & - & - \\
\hline Citrate & - & + & + & - & - & - & - \\
\hline \multicolumn{8}{|l|}{ API 20NE strip results } \\
\hline Nitrate reduction & - & - & + & - & - & - & - \\
\hline Urease & + & - & - & + & - & - & - \\
\hline Aesculin hydrolysis & $\mathrm{W}$ & + & + & + & + & $\mathrm{W}$ & + \\
\hline$\beta$-Galactosidase & - & + & + & + & + & + & + \\
\hline Arabinose assimilation & + & + & - & + & + & + & + \\
\hline Gluconate assimilation & + & - & - & + & - & - & - \\
\hline Malate assimilation & + & - & - & - & + & + & + \\
\hline \multicolumn{8}{|l|}{ Utilization of (API $50 \mathrm{CH}$ ): } \\
\hline Glycerol & - & + & - & - & - & - & + \\
\hline L-Arabinose & + & + & - & + & + & + & + \\
\hline D-Xylose & $\mathrm{w}$ & + & $\mathrm{w}$ & - & + & $\mathrm{w}$ & + \\
\hline Fructose & + & + & - & $\mathrm{W}$ & $\mathrm{W}$ & - & + \\
\hline Rhamnose & + & - & - & - & - & - & - \\
\hline Sorbitol & + & + & - & + & + & + & + \\
\hline Aesculin & - & + & + & $\mathrm{W}$ & - & - & - \\
\hline D-Fucose & + & - & - & + & - & - & - \\
\hline L-Fucose & + & - & - & + & - & - & - \\
\hline Gluconate & + & - & - & + & - & - & - \\
\hline 5-Ketogluconate & $\mathrm{w}$ & - & - & + & - & - & - \\
\hline
\end{tabular}

extends the knowledge of the physiological variability within this species.

The ability of strain $\mathrm{NS}^{\mathrm{T}} 5^{\mathrm{T}}$ to utilize methanol and oxalate was shared with other members of the genus Ancylobacter. However, gas vesicles and chemolithoautotrophy with $\mathrm{H}_{2}$, characteristics of the type species Ancylobacter aquaticus and of Ancylobacter polymorphus, were not detected in $\mathrm{NS} 05^{\mathrm{T}}$. Growth occurred at temperatures up to $40{ }^{\circ} \mathrm{C}$ : this differentiated strain $\mathrm{NS}^{\mathrm{T}} 5^{\mathrm{T}}$ from Ancylobacter aquaticus and Ancylobacter vacuolatus, which grew at temperatures up to 34 and $37{ }^{\circ} \mathrm{C}$, respectively. Strain $\mathrm{NS}^{\mathrm{T}} 5^{\mathrm{T}}$ utilized several carbohydrates and organic acids (Table 2). The results obtained using the API $50 \mathrm{CH}$ panel confirmed the relatively poor metabolic versatility of Ancylobacter aquaticus with regard to carbohydrates, as stated previously (Xin et al., 2006). Comparisons of results obtained in our work using different test methods revealed some deviations, e.g. for utilization of D-arabinose (strains NS03 and NS04 and Ancylobacter polymorphus DSM 2457 ${ }^{\mathrm{T}}$ ) and urease (Ancylobacter rudongensis DSM $17131^{\mathrm{T}}$ ) and the reduction of nitrate (Ancylobacter vacuolatus DSM $1277^{\mathrm{T}}$ ): 
these reactions were negative in the API panels but positive in standard tests. Perhaps the 2 day incubation period for the API strips was not sufficient to allow the development of positive reactions. Strain $\mathrm{NS}^{2} 5^{\mathrm{T}}$ can be distinguished from members of the genus Ancylobacter using the following traits: pleomorphic cell morphology, the ability to utilize D-mannose and L-rhamnose and a negative result in the $\beta$-galactosidase test. Strain $\mathrm{NS}^{2} 5^{\mathrm{T}}$ can be differentiated from its phylogenetically closest neighbour, Ancylobacter rudongensis, which also was incapable of chemolithoautotrophic growth in our hands, by its inability to utilize glycerol and citrate, its ability to utilize fucose, gluconate and malate and its ability to produce a positive urease reaction with the API 20NE strip. Strain $\mathrm{NS}^{\mathrm{T}}{ }^{\mathrm{T}}$ differed from 'Ancylobacter natronum' (as given by Doronina et al., 2001) in being unable to hydrolyse gelatin, to grow chemolithoautotrophically with $\mathrm{H}_{2}$ and to reduce nitrate and in being able to grow at $40{ }^{\circ} \mathrm{C}$. The resistance of strain $\mathrm{NS} 5^{\mathrm{T}}$ to antibiotics and heavy metal ions has been described by Sahin et al. (2002). The results are indicated in the species description.

Genomic and chemotaxonomic data confirm that strain $\mathrm{NS} 5^{\mathrm{T}}$ belongs to the genus Ancylobacter. On the basis of low DNA-DNA hybridization with its closest phylogenetic neighbour and differences in biochemical and morphological traits with respect to all of the type strains described for the genus Ancylobacter, it can be concluded that strain $\mathrm{NS} 05^{\mathrm{T}}$ represents a novel species within the genus, for which the name Ancylobacter oerskovii sp. nov. is proposed.

\section{Description of Ancylobacter oerskovii sp. nov.}

Ancylobacter oerskovii (oers.ko'vi.i. N.L. gen. masc. n. oerskovii of Ørskov, named in honour of J. Ørskov, who, in 1928, described Microcyclus aquaticus, now the type species of the genus Ancylobacter).

Gram-negative and non-motile. Cells are highly pleomorphic rods, $0.5-0.6 \times 0.9-1.7 \mu \mathrm{m}$, and are often boneor droplet-shaped; some coccoid cells are also found. Cells occur singly or in pairs in young cultures and often form clusters (presumably being held together by slime) in older cultures. No spores, gas vesicles or other cell inclusions are found. Non-pigmented. Forms round, cream-coloured, convex colonies, reaching $0.3-0.5 \mathrm{~mm}$ in diameter, on nutrient agar after 2 days incubation; colonies become slimy with age. Growth occurs on nutrient agar slopes at temperatures up to $40{ }^{\circ} \mathrm{C}$. Growth occurs in nutrient broth containing $4 \% \mathrm{NaCl}$. Oxidase- and urease-positive. Negative for chemolithoautotrophic growth with $\mathrm{H}_{2}$, acid production from glucose, nitrate reduction, indole production, arginine dihydrolase, gelatin hydrolysis and $\beta$ galactosidase. Utilizes methanol, oxalate, glucose, galactose, D-fucose, L-fucose, fructose, L-arabinose, rhamnose, Darabitol, mannitol, sorbitol, xylitol, gluconate, malate and malonate. Does not utilize glycerol, $\mathrm{N}$-acetylglucosamine or 2-ketogluconate. The main fatty acids are $\mathrm{C}_{18: 1} \omega 7 c$ $(60.4 \%), \mathrm{C}_{19: 0} \omega 8 c$ cyclo $(28.3 \%)$ and $\mathrm{C}_{16: 0}(7.4 \%)$; minor amounts of $\mathrm{C}_{17: 0}$ and $\mathrm{C}_{18: 0}$ and an unknown component are present. Contains ubiquinone Q-10 and minor amounts of Q-9. The DNA G+C content is $68.0 \mathrm{~mol} \%$. The type strain is resistant to ampicillin and bacitracin (each at $10 \mu \mathrm{g}$ per disc), erythromycin $(15 \mu \mathrm{g})$ and chloramphenicol $(30 \mu \mathrm{g})$ and susceptible to gentamicin and streptomycin $\left(10 \mu \mathrm{g}\right.$ each). Sensitive to $\mathrm{HgCl}_{2}$ $\left(2.5 \mu \mathrm{g}\right.$ on disc) and resistant to $\mathrm{ZnSO}_{4} \cdot 7 \mathrm{H}_{2} \mathrm{O}$, $\mathrm{NiCl}_{2} \cdot 6 \mathrm{H}_{2} \mathrm{O}, \mathrm{CoCl}_{2} \cdot 6 \mathrm{H}_{2} \mathrm{O}, \mathrm{CuSO}_{4} \cdot 5 \mathrm{H}_{2} \mathrm{O}$, lead acetate and $\mathrm{K}_{2} \mathrm{CrO}_{7}$ (each at $2.5 \mu \mathrm{g}$ per disc).

The type strain, NS05 ${ }^{\mathrm{T}}\left(=\mathrm{DSM} 18746^{\mathrm{T}}=\mathrm{CCM} 7435^{\mathrm{T}}\right)$, was isolated from soil using mineral medium with oxalate for enrichment.

\section{Acknowledgements}

We are grateful to M. Rohde (Helmholtz Centre for Infection Research, Braunschweig, Germany) for providing the field emission scanning electron microscopic image, and to R. Kroppenstedt (DSMZ) for providing fatty acid analyses. We wish to thank M. Kopitz, P. Aumann, S. Welnitz, I. Kramer, B. Sträubler and J. Gregor for excellent technical assistance.

\section{References}

Aragno, M. \& Schlegel, H. G. (1992). The mesophilic hydrogenoxidizing (Knallgas) bacteria. In The Prokaryotes, 2nd edn, pp. 344384. Edited by A. Balows, H. G. Trüper, M. Dworkin, W. Harder \& K. H. Schleifer. Berlin: Springer.

Cashion, P., Holder-Franklin, M. A., McCully, J. \& Franklin, M. (1977). A rapid method for the base ratio determination of bacterial DNA. Anal Biochem 81, 461-466.

Collins, M. D., Pirouz, T., Goodfellow, M. \& Minnikin, D. E. (1977). Distribution of menaquinones in actinomycetes and corynebacteria. $J$ Gen Microbiol 100, 221-230.

De Ley, J., Cattoir, H. \& Reynaerts, A. (1970). The quantitative measurement of DNA hybridization from renaturation rates. Eur $J$ Biochem 12, 133-142.

De Soete, G. (1983). A least squares algorithm for fitting additive trees to proximity data. Psychometrika 48, 621-626.

Doronina, N. V., Darmaeva, Ts. D. \& Trotsenko, Yu. A. (2001). Novel aerobic methylotrophic isolates from the soda lakes of the southern Transbaikal region. Microbiology (English translation of Mikrobiologiia) 70, 342-348.

Fritz, I., Strömpl, C. \& Abraham, W.-R. (2004). Phylogenetic relationships of the genera Stella, Labrys and Angulomicrobium within the 'Alphaproteobacteria' and description of Angulomicrobium amanitiforme sp. nov. Int J Syst Evol Microbiol 54, 651-657.

Garrity, G. M., Bell, J. A. \& Lilburn, T. (2005). Family VIII. Hyphomicrobiaceae Babudieri 1950, 589. In Bergey's Manual of Systematic Bacteriology, 2nd edn, vol. 2, part C, p. 476. Edited by D. J. Brenner, N. R. Krieg, J. T. Staley \& G. M. Garrity. New York: Springer.

Groth, I., Schumann, P., Rainey, F. A., Martin, K., Schuetze, B. \& Augsten, K. (1997). Demetria terragena gen. nov., sp. nov., a new genus of actinomycetes isolated from compost soil. Int J Syst Bacteriol 47, 1129-1133.

Huß, V. A. R., Festl, H. \& Schleifer, K. H. (1983). Studies on the spectrophotometric determination of DNA hybridization from renaturation rates. Syst Appl Microbiol 4, 184-192. 
Kämpfer, P. \& Kroppenstedt, R. M. (1996). Numerical analysis of fatty acid patterns of coryneform bacteria and related taxa. Can J Microbiol 42, 989-1005.

Lee, K.-B., Liu, C.-T., Anzai, Y., Kim, H., Aono, T. \& Oyaizu, H. (2005). The hierarchical system of the 'Alphaproteobacteria': description of Hyphomonadaceae fam. nov., Xanthobacteraceae fam. nov. and Erythrobacteraceae fam. nov. Int J Syst Evol Microbiol 55, 1907-1919.

Malik, K. A. (1988). A new freeze-drying method for the preservation of nitrogen-fixing and other fragile bacteria. J Microbiol Methods 8, 259-271.

Mesbah, M., Premachandran, U. \& Whitman, W. B. (1989). Precise measurement of the $\mathrm{G}+\mathrm{C}$ content of deoxyribonucleic acid by highperformance liquid chromatography. Int J Syst Bacteriol 39, 159-167.

Ørskov, J. (1928). Beschreibung eines neuen Mikroben, Microcyclus aquaticus, mit eigentuemlicher Morphologie. Zentralbl Bakteriol Parasitenkd Infektionskr Hyg Abt I 107, 180-184 (in German).

Raj, H. D. (1983). Proposal of Ancylobacter gen. nov. as a substitute for the bacterial genus Microcyclus Ørskov 1928. Int J Syst Bacteriol 33, 397-398.

Raj, H. D. (1989). Oligotrophic methylotrophs: Ancylobacter (basonym “Microcyclus" Ørskov) Raj gen. nov. Crit Rev Microbiol 17, 89-106.

Sahin, N. (2003). Oxalotrophic bacteria. Res Microbiol 154, 399-407. Sahin, N., Gökler, I. \& Tamer, A. Ü. (2002). Isolation, characterization and numerical taxonomy of novel oxalate-oxidizing bacteria. J Microbiol 40, 109-118.

Saitou, N. \& Nei, M. (1987). The neighbor-joining method: a new method for reconstructing phylogenetic trees. Mol Biol Evol 4, 406-425.
Sasser, M. (1990). Identification of bacteria by gas chromatography of cellular fatty acids. USFCC Newsl 20, 16.

Smibert, R. M. \& Krieg, N. R. (1994). Phenotypic characterization. In Methods for General and Molecular Bacteriology, pp. 607-655. Edited by P. Gerhardt, R. G. E. Murray, W. A. Wood \& N. R. Krieg. Washington, DC: American Society for Microbiology.

Somvanshi, V. S., Lang, E., Sträubler, B., Spröer, C., Schumann, P., Ganguly, S., Saxena, A. K. \& Stackebrandt, E. (2006). Providencia vermicola sp. nov., isolated from infective juveniles of the entomopathogenic nematode Steinernema thermophilum. Int J Syst Evol Microbiol 56, 629-633.

Tamaoka, J. \& Komagata, K. (1984). Determination of DNA base composition by reversed-phase high-performance liquid chromatography. FEMS Microbiol Lett 25, 125-128.

Urakami, T. \& Komagata, K. (1973). Cellular fatty acid composition and coenzyme $Q$ system in Gram-negative methanol-utilizing bacteria. J Gen Appl Microbiol 25, 343-360.

Urakami, T. \& Komagata, K. (1986). Methanol-utilizing Ancylobacter strains and comparison of their cellular fatty acid compositions and quinone systems with those of Spirosoma, Flectobacillus, and Runella species. Int J Syst Bacteriol 36, 415-421.

Xin, Y. H., Zhou, Y. G., Zhou, H. L. \& Chen, W. X. (2004). Ancylobacter rudongensis sp. nov., isolated from roots of Spartina anglica. Int J Syst Evol Microbiol 54, 385-388.

Xin, Y. H., Zhou, Y. G. \& Chen, W. X. (2006). Ancylobacter polymorphus sp. nov. and Ancylobacter vacuolatus sp. nov. Int J Syst Evol Microbiol 56, 1185-1188. 